\title{
Insights into the structure and surface geology of balanced and retrodeformed geological cross sections from the Nizampur basin, Khyber Pakhtunkhwa, Pakistan
}

\author{
Muhammad Yaseen ${ }^{1}$ (D) Muhammad Shahab ${ }^{2} \cdot$ Zeeshan Ahmad $^{1} \cdot \operatorname{Rehman~Khan~}^{1} \cdot$ Syed Farhan Ali Shah ${ }^{1}$. \\ Abbas Ali Naseem ${ }^{3}$
}

Received: 7 February 2021 / Accepted: 30 April 2021 / Published online: 9 May 2021

(c) The Author(s) 2021

\begin{abstract}
The current research work is an attempt to apply the basic geological procedures, methods of geological mapping, surface and subsurface interpretation and restoration of balanced and retrodeformed cross sections from the Nizampur basin, Khyber Pakhtunkhwa, Pakistan. The work also includes the documentation of several surface structural features, i.e., anticlines, synclines and different types of folds and faults exposed in the vicinity of study area. Four central thrust faults were recognized named as Kahi Thrusts along the cross sections. These thrust faults carried the older sequences of rocks over the younger sequences in different portion along the measured cross section. The folded and faulted rocks in the area show that stratigraphic framework comprises of Eocene, Paleocene, Cretaceous and Jurassic succession of rocks. There are Eocene rocks existing in the extreme South of the mapped area with addition of older Cretaceous and Jurassic succession and contains simple and large-scale folds, faults and back thrust. Two structural transect were mapped which encounter different folds and faults, i.e., X-sections AB oriented NS and CD oriented NE-SW. Restoration of the structural transects was calculated and assumed that at the formation of Main Boundary Thrust, the study area was exposed to the tectonic forces which prognosticated $19.5 \%$ shortening in rock sequences from Jurassic to Eocene succession along the measured cross section A_B.
\end{abstract}

Keywords Geological mapping · Retrodeformed X-section · Nizampur basin $\cdot$ KP · Pakistan

\section{Introduction}

The study area is located in the Nizampur basin Kahi valley of Khyber Pakhtunkhwa, North West Pakistan. The focused area is bounded with coordinates N $33^{\circ} 48^{\prime} 52.99^{\prime \prime}$, $\mathrm{E} 72^{\circ} 03^{\prime} 18.80^{\prime \prime}$ and is divided into two parts with younger Eocene rocks to the East and sequentially older Paleocene, Cretaceous and Jurassic successions exposed to the West of the mapped area. The study area located in the vicinity of the Main Boundary Thrust fault (MBT) has experienced

Muhammad Yaseen

yaseengeo@awkum.edu.pk

1 Department of Geology, Abdul Wali Khan University Mardan, Mardan, Khyber Pakhtunkhwa, Pakistan

2 National Center of Excellence in Geology, University of Peshawar, Peshawar, Pakistan

3 Department of Earth-Science, Quaid-i-Azim University, Islamabad, Pakistan intense deformation and shortening resulting in thrust faults and various large- and small-scale folds. This area signifies the foot and hanging wall of the Hissartang fault and Main Boundary Thrust correspondingly. Sandwiched among these two faults, the study area has experienced intense compression (Fig. 1). Recently, diverse approaches have been made to the Nizampur and adjoining area consists mostly on study of sequence stratigraphy, reservoir quality, Geochemistry along microfacies of various successions, i.e., Khan et al. (2020); Hashmi et al. (2018). Awais et al. (2013) mapped and performed structure analysis of a part of Kala Chitta Range near Kahi Nizampur. Other works include Kazmi and Jan, 1997 on geology and tectonics of Nizampur, Yeats and Hussain (1987) studied timing of structural events in Himalayan foothills of northwestern Pakistan. The present work involves surface mapping and structural analysis of two transects oriented NS and NE-WS along with other major and minor structural features.

This research work is aimed at covering the following objectives: 


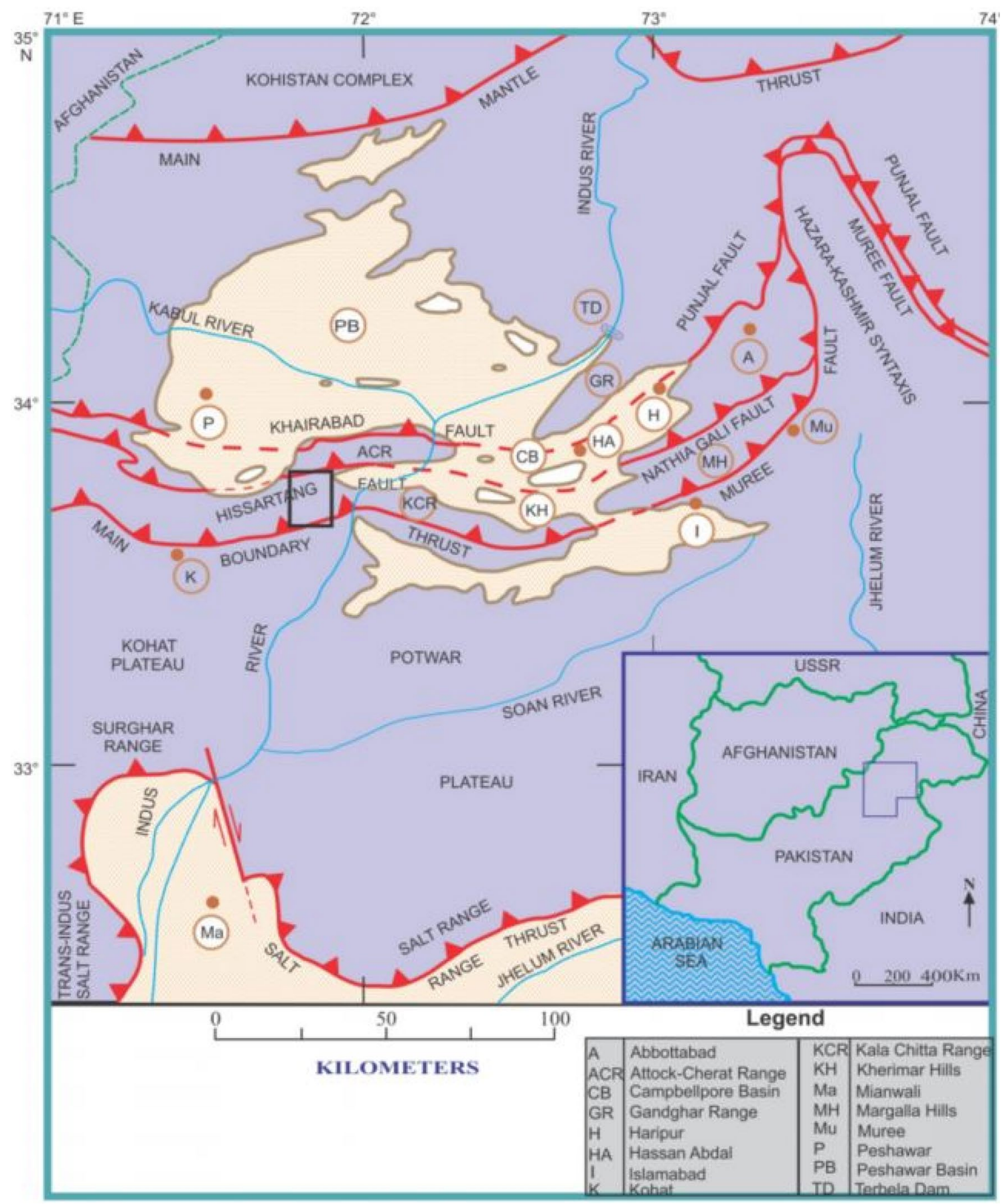

Fig. 1 Generalized tectonic map of northern Pakistan, showing regionally significant structural boundaries and geographic localities. The black rectangle in the preset marks the location of the study area (adopted and modified after Calkins et al. 1975, Hylland and Riaz 1988, Hashmi et al. 2018)

\section{Geological setting of the study area}

Tectonically, the mapped area is enclosed by the region of active thrusting and folding in the foreland of the $2489 \mathrm{~km}$ long Himalayan highland in Pakistan, therefore, showing

- Restoration of the deformed cross sections, leading to calculation of the total shortening in area. 
a complicated structural arrangement (Yeats and Hussain 1987). The Attock-Cherat Range (ACR) is positioned between Peshawar Basin on the north and Kala Chitta Range on the south (Burbank and Johnson 1982). The boundary between ACR and Kala Chitta Range is delineated by Hissartang Thrust in Nizampur basin, where it splits the southern slab of ACR from Kala Chitta Range (Yeats and Hussain 1987). Movement along the Hissartang thrust deformed the rocks of ACR and Kala Chitta Range (Ghauri et al. 1991). In ACR, sediments of Pre-Cambrian to Paleocene are outcropping. The ACR bound the area to the north and includes metasedimentary rocks of the lesser Himalayas. The foreland basin strata of the Kala Chitta Range bound the area toward the south (Hashmi et al. 2018). The study area located in the vicinity of the Main Boundary Thrust fault (MBT) has experienced intense deformation and shortening resulting in thrust faults and various large and small-scale folds. In the area, the rocks exposed in the ACR and those exposed at the Kahi gorge are highly folded. The Kahi gorge lies in the Himalayan foothills of Nizampur valley in Khyber Pakhtunkhwa of North West Pakistan. The Kala Chitta Range (KCR) is a part of the active Himalayan Foreland Fold-and-Thrust Belt which has progressively been verged southward in a series of top to the south thrust imbricates along Main Boundary Thrust (MBT), fabricating the regional fault system of Northern Pakistan (Wadood et al. 2019). Tectonic map of northern Pakistan, the black rectangle in the preset marks the location of the study area as shown in Fig. 1 adopted and modified after Yaseen et al. (2021a, b); Hashmi et al. (2018); Hylland and Riaz (1988); and Calkins et al. (1975).

\section{Stratigraphic framework}

The study area consists of rocks from Jurassic to Recent lacustrine sediments, including Jurassic Samanasuk formations; Cretaceous; Chichali, Lumshiwal, and Kawagarh formations; Palaeocene; Hangu, Lockhart, and Patala formations, and Eocene; Margalla Hill Limestone (Hashmi et al. 2018). The exposed Formations in the study area are Margalla hill Limestone toward the east of mapped area and Hangu Formation, Lockhart Formation, Patala Formation, Chichali Formation, Lumshiwal Formation, Kawagarh Formation and Samanasuk Formation toward the west of mapped area. The generalized stratigraphic chart of the study area is shown in (Fig. 2c after Awais et al. 2012).

\section{Methodology}

Detailed geological field was conducted to study the area. This research project is mostly based on collected data from fieldwork. The applied methods remained conventional including structural and stratigraphic mapping. The collected geological data were organized, examined and presented using software such as Google Earth, Global Mapper, Coral Draw and final MOVE 2016.1 for cross section and restoration. The outcrop studies include location and assemblies of folds, faults, stylolites and all other structural features. The outcrop studies were followed by data collections including the measurement of strike, dip, fault planes and vertical stylolites. The software work covered the preparation of final structural map, followed by several process including identification of research area in Google Earth leading to line work on study area. Line work was then transferred to Global Mapper for corrections. Global Mapper outputs were then transferred to Coral Draw for smoothening the edges and application of further corrections. After completion, data were transferred to 2D Move software for structural modeling of the cross sections and then to calculate the total amount of shortening in study area. The simple shear (flexural slip folding deformation) and total/partial shortening methods were employed for restoration as followed by Yaseen et al. (2021a, b) and Omar et al. (2015), respectively. Preliminary step comprises restoring move on faults for minimizing dislocations on each faults. All the faults listed in the cross section were reinstated by means of the software feature algorithm "2D Move on Fault." The technique of "Fault parallel flow" is applied to restore the movement contained by a fault where varied values are applied to the attribute unless all the strata became flawlessly restored which display constancy over the fault.

\section{Structural analysis}

The study area is tectonically located near Main Boundary Thrust fault, which has ACR toward the North and KCR toward the South as shown in Fig. 1. The stresses enlightened due to deformation of MBT produced several phases of strains and deformations in the exposed successions of rocks along the Khware Khwar section. The succession subjected to the deformational stresses starts from Eocene and lasts up to Jurassic Formations. After deformation, the mapped area displayed several types of structures that are divided into plunging, overturned, major and minor folds along with faults, the four thrust faults KTs, and anticlines and synclines, as shown in the constructed geological map Fig. 3. Following structural features were observed and represent the deformation in the area:

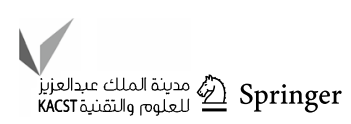


(A)

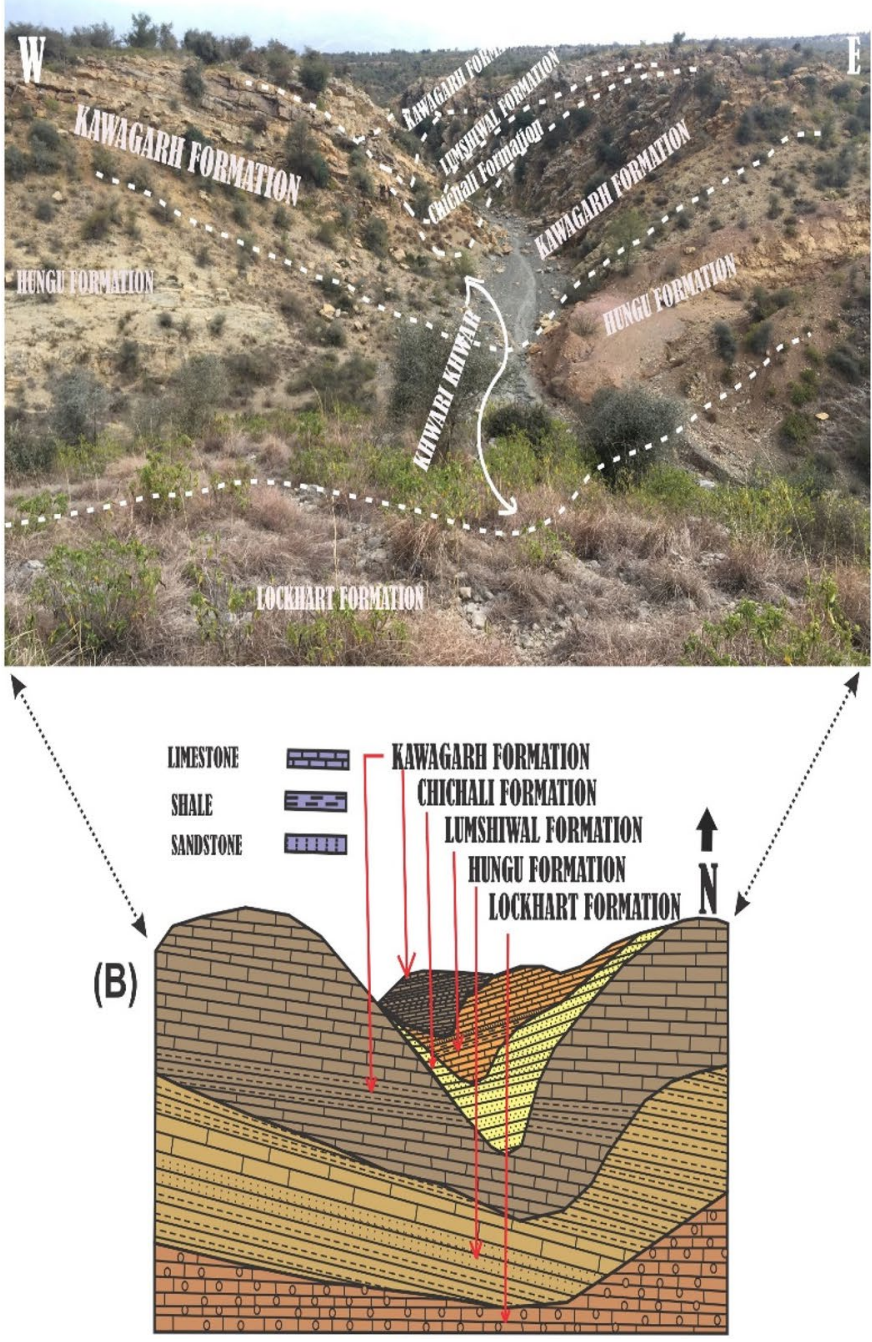

(C)

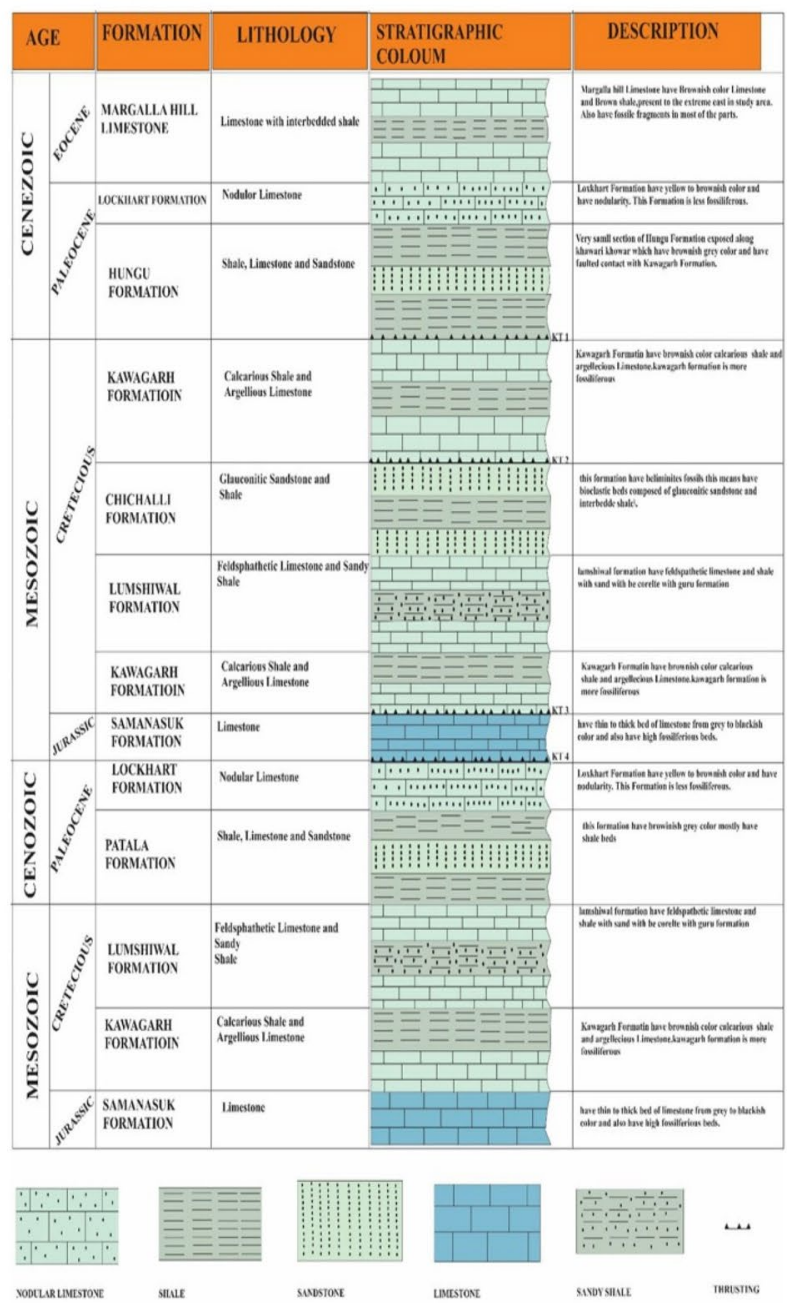

Fig. 2 a Showing the exposed outcrop with different formations oriented in E-W direction b Generalized structural geometry of study area and sequence of formations along Khware Khwar from oriented

\section{Fold types}

The dominant structure feature in study area particularly in Kahi Gorge is folds, which tilted the strata and created deformation. On the basis of geometries of folds, the folds are divided into different geometrical types including symmetrical, asymmetrical, overturned, monoclinal, S \& $\mathrm{Z}$ types and plunging folds. All of these are explained below individually and shown in (Fig. 4a-d).

\section{Plunging fold}

A plunging fold is a fold that is tilted downward in space, parallel to the fold hinge plane. The Samanasuk formation to the extreme north of the mapped area shows double plunging
$\mathrm{N}-\mathrm{S}$. c The generalized stratigraphic chart of the study area showing successions form Jurassic to Eocene and it is not up to scale (after Awais et al. 2012)

folds, in which the hinge lines plunge toward the east, example in Fig. 4a.

\section{Symmetrical fold}

Symmetric fold, with axial plain in vertical direction, can be observed repeatedly in the Kahi Gorge lies in the vicinity of the cross section AB oriented NS. These folds are observed in Kawagarh formation. An example is shown in Fig. 4b.

\section{Asymmetrical fold}

The Kawagarh and Chichali Formation exhibit overturned folds. The axial plains of the folds are in tilted positions from horizontal. The folds of this kind are 


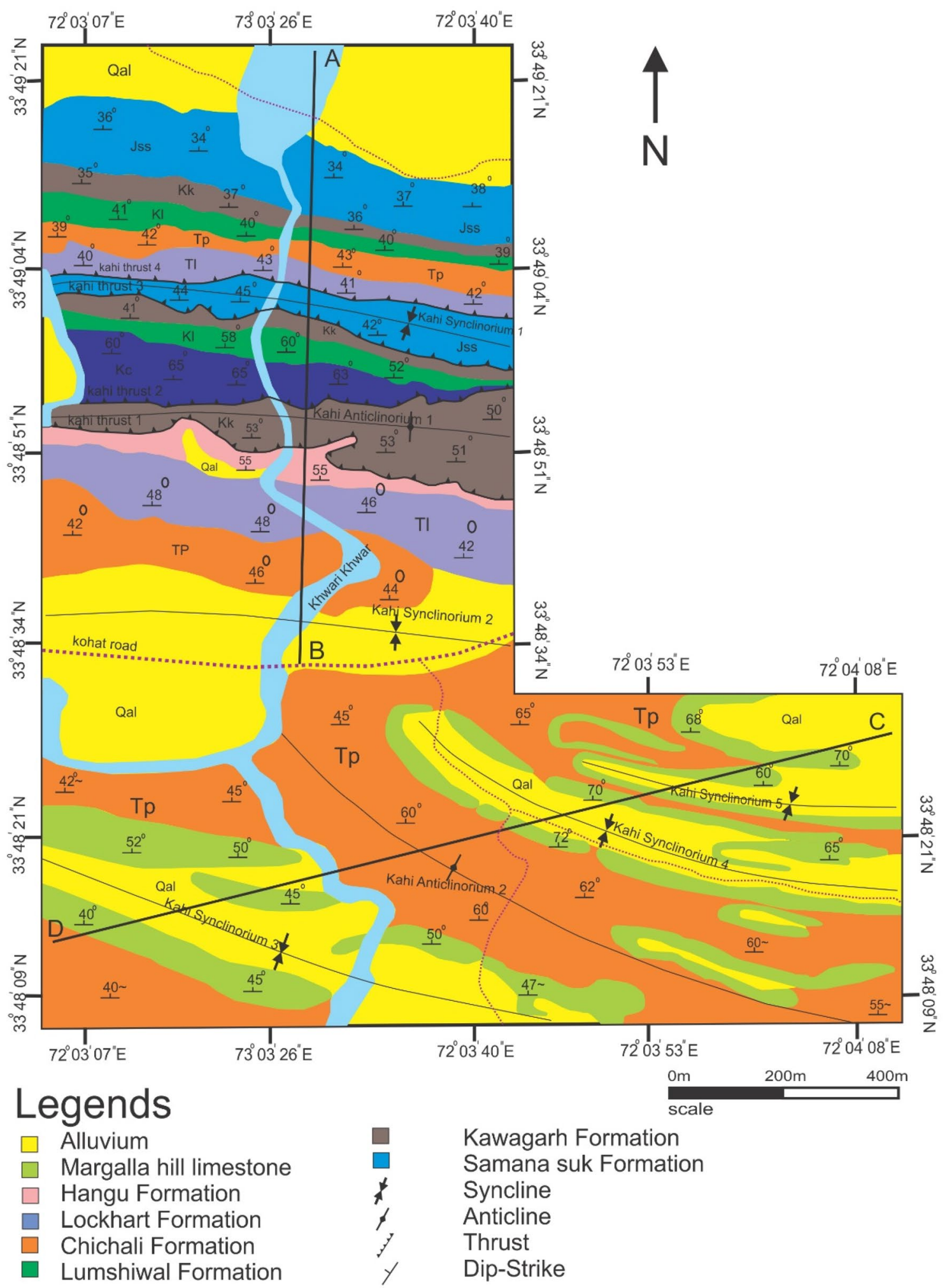

Fig. 3 Geological map of the Kahi Gorge section along the Khware Khwar. The two cross sections AB oriented NS and CD oriented NE-SW are constructed which are covering most of the geological structures present in the mapped area 

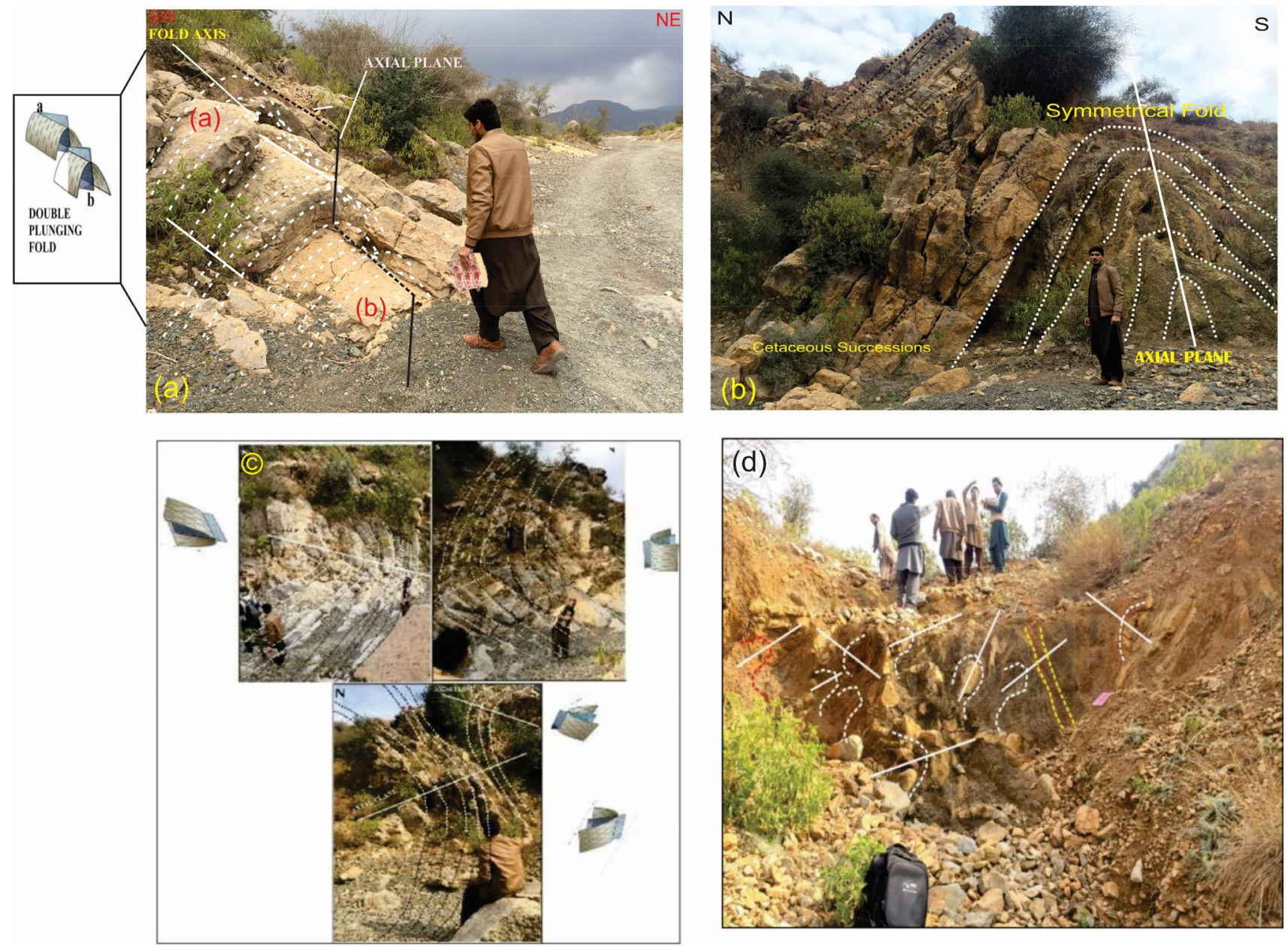

Fig. 4 a Showing the Samanasuk formation to the extreme north of the mapped area shows double plunging folds, in which the hinge lines plunge toward b Symmetric fold, with axial plain in vertical direction, observed in Kawagarh formation c Overturn folds present in Chichalli and Kawagarh formations $\mathbf{d}$ Minor folds $\mathrm{S}$ and $\mathrm{Z}$ types are present in the Paleocene rocks Patala Formation which are evident of shear zone generally produced either by gravity gliding or in a layer on minor scale that is appreciably inclined (but less than 45 degrees) to the principal shortening direction Fig. 4c.

\section{$S$ and $Z$ type folds}

Minor folds can have $\mathrm{S}$ or $\mathrm{Z}$ shapes depending on their sense of asymmetry and these in turn can give rise to complex refolded shapes. The outcrop patterns developed are typical of the type of superposition of two sets of fold structures. These folds are present in the Paleocene rocks Patala Formation which are evident of shear zone. The geometric disposition of $\mathrm{S}$ and Z-folds is extremely useful for deciphering large-scale folds, particularly when exposure is incomplete Fig. 4d.

\section{Monoclinal fold}

The Kawagarh Formation between Chichali and Patala formation displays the monoclinal folds in which the one limb exists while the other limb is eroded. Monoclines are folds consisting of two horizontal (or nearly so) limbs connected by a shorter inclined limb. The form of a monoclinal drape fold is controlled in part by the nature of the underlying fault (normal, reverse or vertical) and in part by the mechanical nature of the strata being folded Fig. 5a.

\section{Anticlinorium and synclinorium}

A large or major anticline or a syncline on whose limbs are found minor folds, both anti- and synclines, generally asymmetrical and of opposite senses on the two limbs. Kahi 


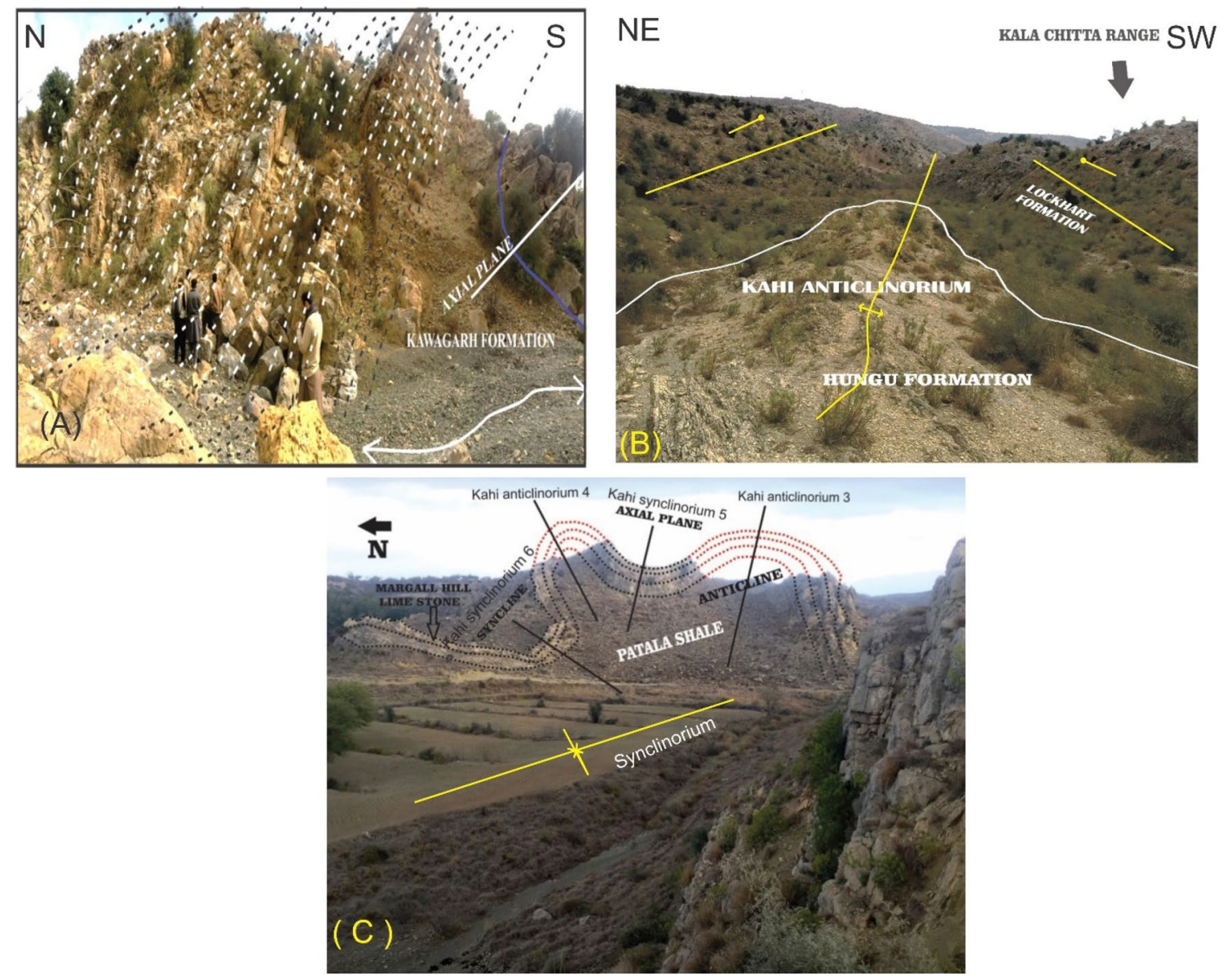

Fig. 5 a showing the Monoclinal fold present along the cross section $\mathrm{AB}$ in mapped area exposed in Kawagarh Formation b showing the Kahi Anticlinorium cored by Hangu Formation and Lockhart Forma-

anticlinorium is another dominant structure toward the south before Kawagarh formation. Kahi anticlinorium shows dipping away from center toward the north and the south. Moreover, the Kahi synclinorium is present next to the Chichali formation which shows dipping from the north and the south toward the center of the synclinorium as shown in Fig. 5b, c, respectively.

\section{Thrust types and nature}

The study area shows different types and nature of thrust faults in which older rocks thrusted over younger rocks. There are four main thrusts, as shown in Fig. 6a-f. KT1 is the first thrust fault located on the cross section line $\mathrm{AB}$ and is present between cretaceous and Paleocene. There is very excellent exposure of the fault with clear fault gouge present at the fault plane as shown in Fig. 6a. KT2 is the second thrust fault where the Jurassic thrusted over the cretaceous Formation. KT3 is the third thrust of the area and is located between the Samanasuk formation of Jurassic tion at the limbs $\mathbf{c}$ illustrates series of anticlinorium and synclinorium exposed at the cross section line CD in the Margalla hill limestone of Eocene age

age and Kawagarh formation of Cretaceous age. In KT3, Samanasuk formation is thrusted over Kawagarh formation as shown in Fig. 6b, c. KT4 is the last thrust present between the Paleocene and Jurassic. At KT4, the Paleocene rocks (Lockhart formation) are thrusted over Jurassic rocks (Samanasuk formation), as shown in Fig. 6. The deformation in the research area also produces strains in the form of small-scale faults and gash veins. Figure 6e shows example of such small-scale faults mainly exposed in the nodular Lockhart formation.

\section{Structural modeling of cross sections}

The structural features mapped in the study area include variety of folds and faults, i.e., overturned and asymmetrical folds. The perpetual erosion of rock layers on the surface led to difficulties in elaboration of the subsurface modeling. However, after adopting the principal structural and restoration techniques, the geological map of the research area and the two cross sections viz. AB oriented NS and DC oriented 

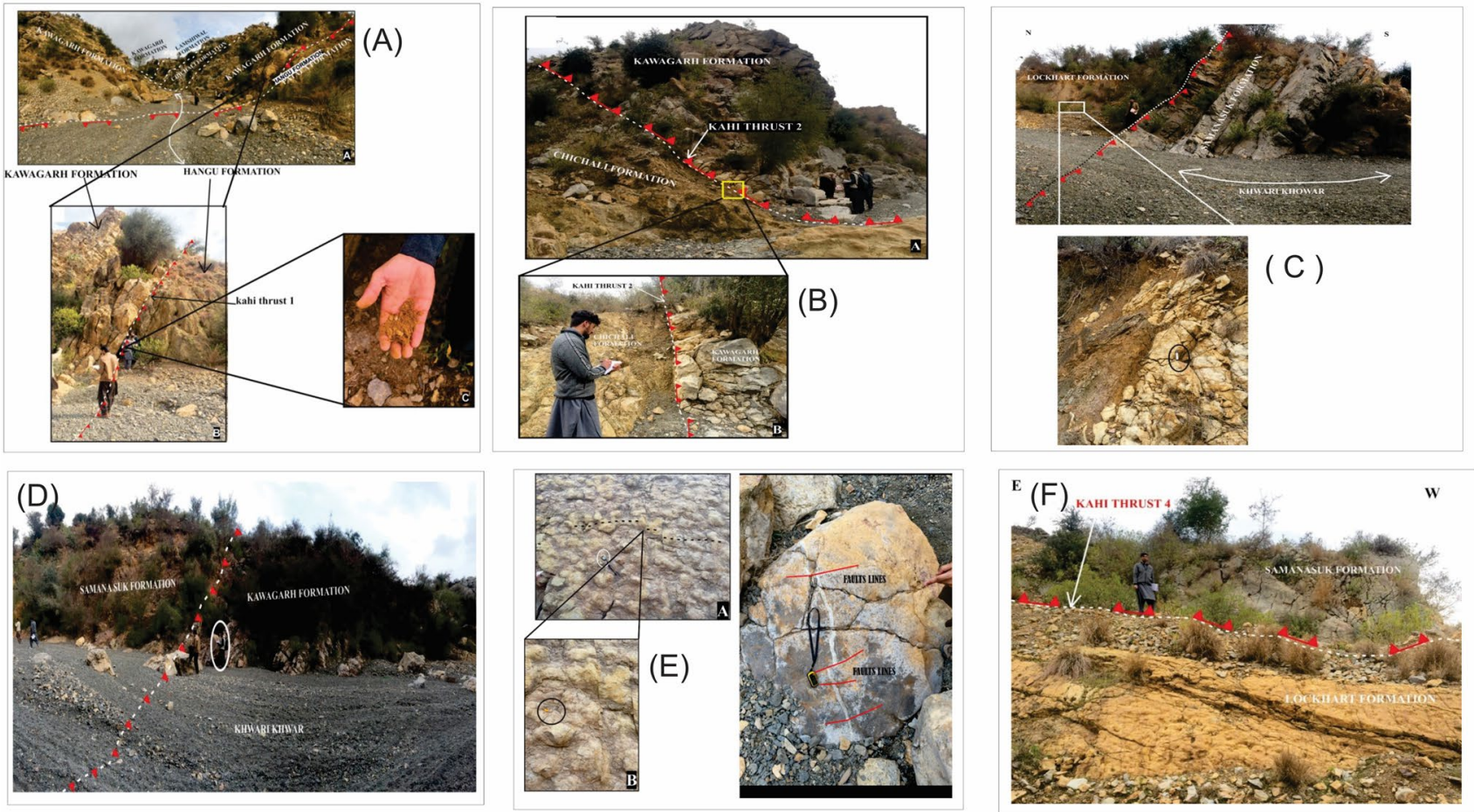

Fig. 6 Displaying the different faults types and nature exposed in the mapped area a showing the KT1 where cretaceous thrust over Paleocene having the Fault gouge at the Fault plane. b Showing the KT 2 where the Jurassic thrusted over the cretaceous Formation c show-

NE-SW was constructed, which result from the transformation of surface data into the subsurface data. These cross sections help us in visualizing the faults to establish the exact number of faults. In order to elaborate our findings and interpretation of the internal structures and their geometries, we made the two cross sections ( $\mathrm{AB}$ and $\mathrm{CD}$ ) mentioned earlier and explained below:

\section{Geological cross sections (A-B) and (C-D)}

The cross section $\mathrm{AB}$ is oriented in NS direction. All the trust faults, i.e., KT1, KT2, KT3 and KT4 along with Anticlinorium and Synclinorium lie on this cross section. The $\mathrm{AB}$ cross section throws light on the subsurface information regarding geometries of the above-mentioned structures with respect to their positions in the northwest portion of the research area; as shown in Fig. 7. The AB cross section shows the alluvium covering the Samanasuk formation and Patala formation in the north and the south, respectively. Toward north, this cross section shows KT4 which comes from approximately $300 \mathrm{~m}$ depth and has Lockhart formation thrusted over Samanasuk formation. The structural transect along the section line $\mathrm{AB}$ is perpendicular to the trend of the major structures present in the area and is north oriented. The northern most part of the ing the KT 3 where the Samanasuk formation thrusted over Kawagarh formation $\mathbf{d}$ and $\mathbf{f}$ Exhibiting KT4 with Paleocene thrusted over Jurassic successions e showing small-scale faults mainly exposed in the nodular Lockhart formation

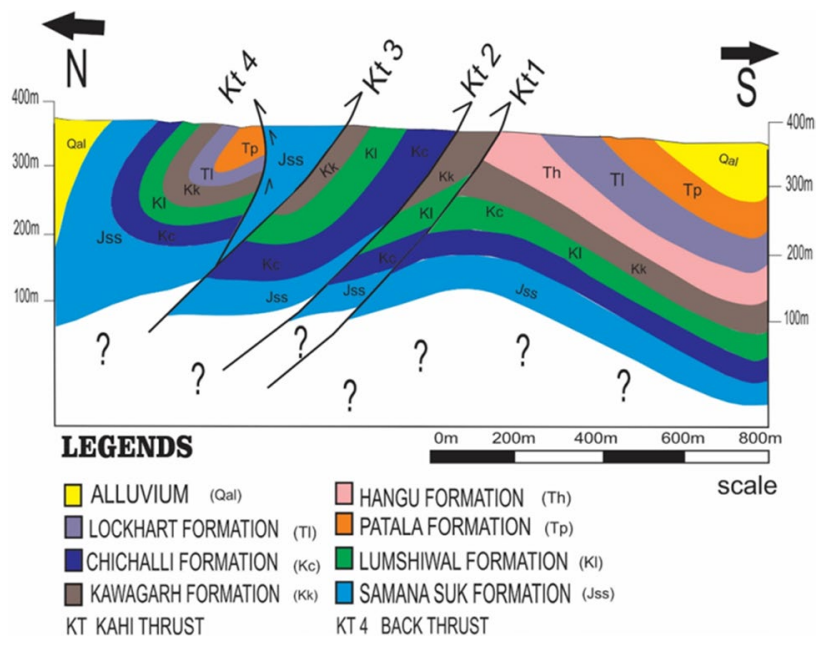

Fig. 7 Geological cross section line A-B oriented in north-south direction. The structural transect along the section line $\mathrm{AB}$ is perpendicular to the trend of the main structures present in the area and is north oriented

area is covered by the Jurassic rocks Samanasuk Formations. Folding and faulting are very intense in Patala and Chichali Formations. It may be the reason because it is composed of competent and incompetent lithologies. The 
incompetent lithology is shale and competent lithology is limestone. There is an anticline and syncline besides the faults present in the area. The anticline contains Samanasuk Formation in the core and Chichali Formation at the limbs while the syncline consists of Patala Formation at the core and Lockhart Limestone at the limbs. As the overall tectonic transport of the area is toward the south but some thrusts vergence toward the north, consider to be back thrusts. Overall the structural style of the study area is characterized by south verging high angle reverse

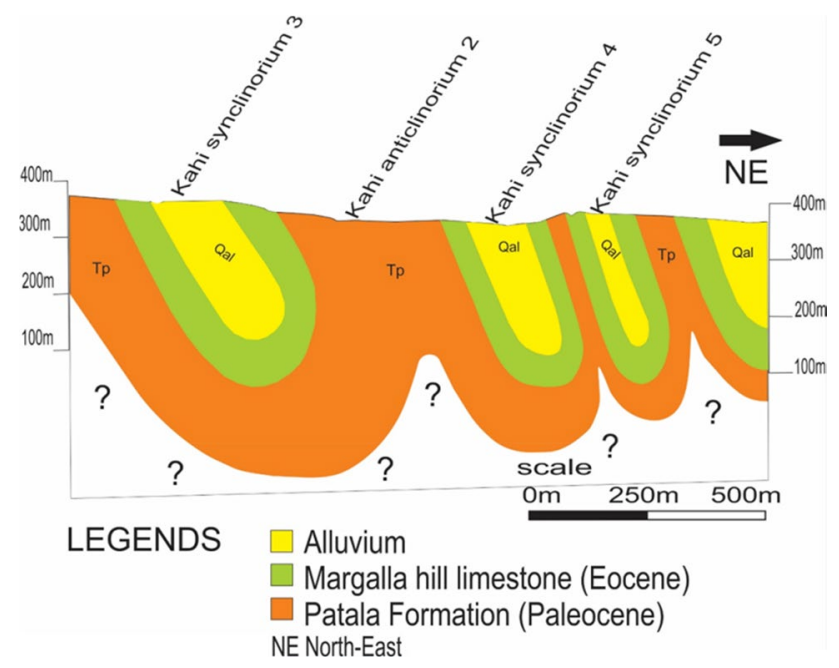

Fig. 8 Geological cross section C-D oriented in NE-SW direction gives detailed information of different series of anticlinorium and synclinorium which are located in the NE and SW of the mapped area. Synclinorium is mostly cored by Paleocene successions faults associated with stresses released during collision tectonics. Such minute observations might be described in regional tectonic framework (thin skinned or thick skinned). The cross section CD is oriented NE-SW covers the structural geometries in the east of the study area. The $\mathrm{CD}$ cross section gives detailed information of different series of anticlinorium \& synclinorium which are located in the NE and SW of the mapped area. Synclinorium is mostly cored by Patala Formation. The anticlinorium has Margalla hill Limestone in the core, while at the limbs, it has Paleocene succession of rocks (Fig. 8).

\section{Restorations}

Restoration of the cross section A-B was performed through three major phases, first applied reverse movements to bring the model back to its original position and then applied simple shear (flexural slip folding deformation) mechanism on every individual stratum to find out the shortening percentage in it, as shown in Figs. 9 and 10. The vertical and lateral changes in style of folding in relation to the rheology of the stratigraphic pile are thoroughly described in Yaseen et al. 2021a, b and Omar et al. 2015, respectively. Following the same, in order to establish the percentage shortening, the subsequent formula is used for calculation as shown in the table as follows;

$\%$ of shortening $=\Delta L / L r \times 100$.

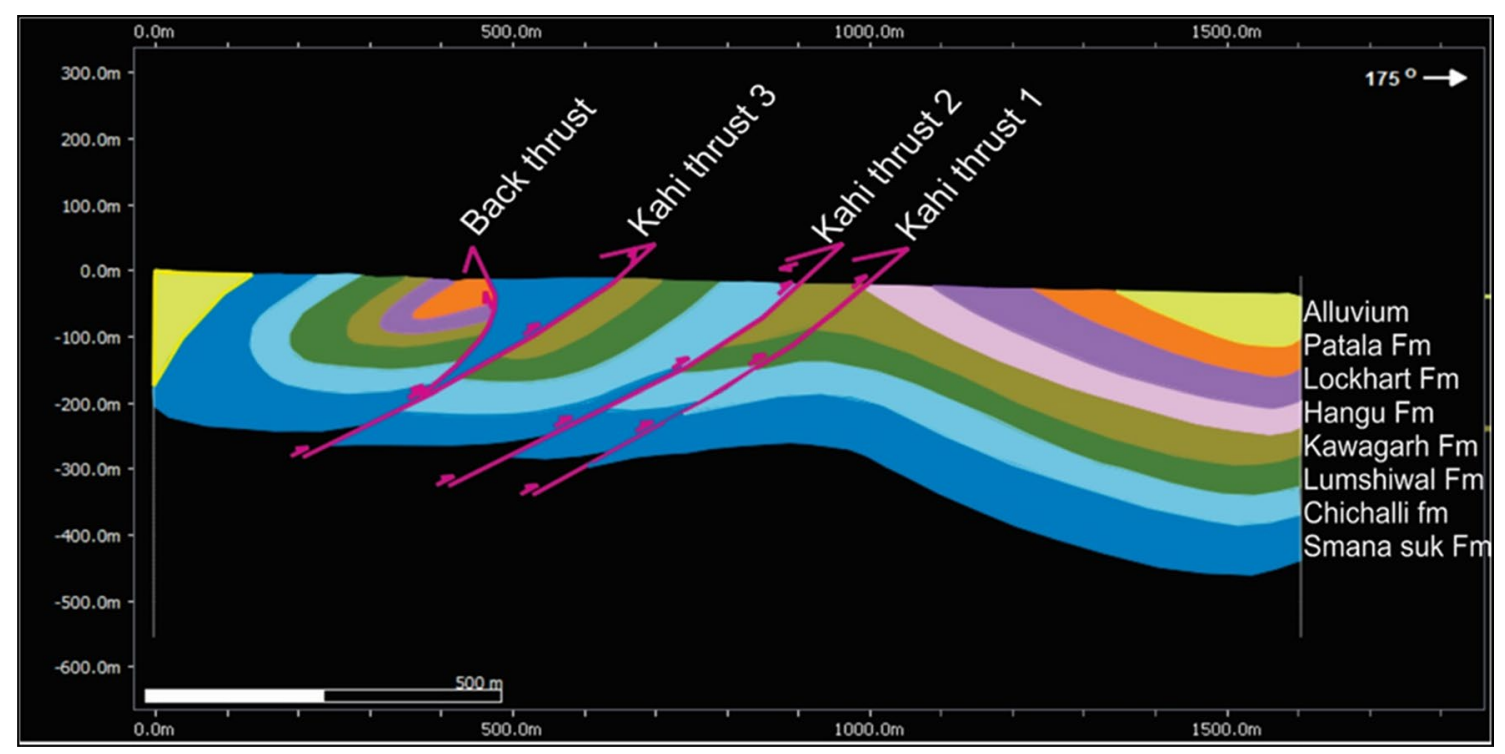

Fig. 9 Geological cross section AB oriented N-S constructed in Move suite where all the formations and faults are marked properly for applying the flexural slip folding deformation mechanism 


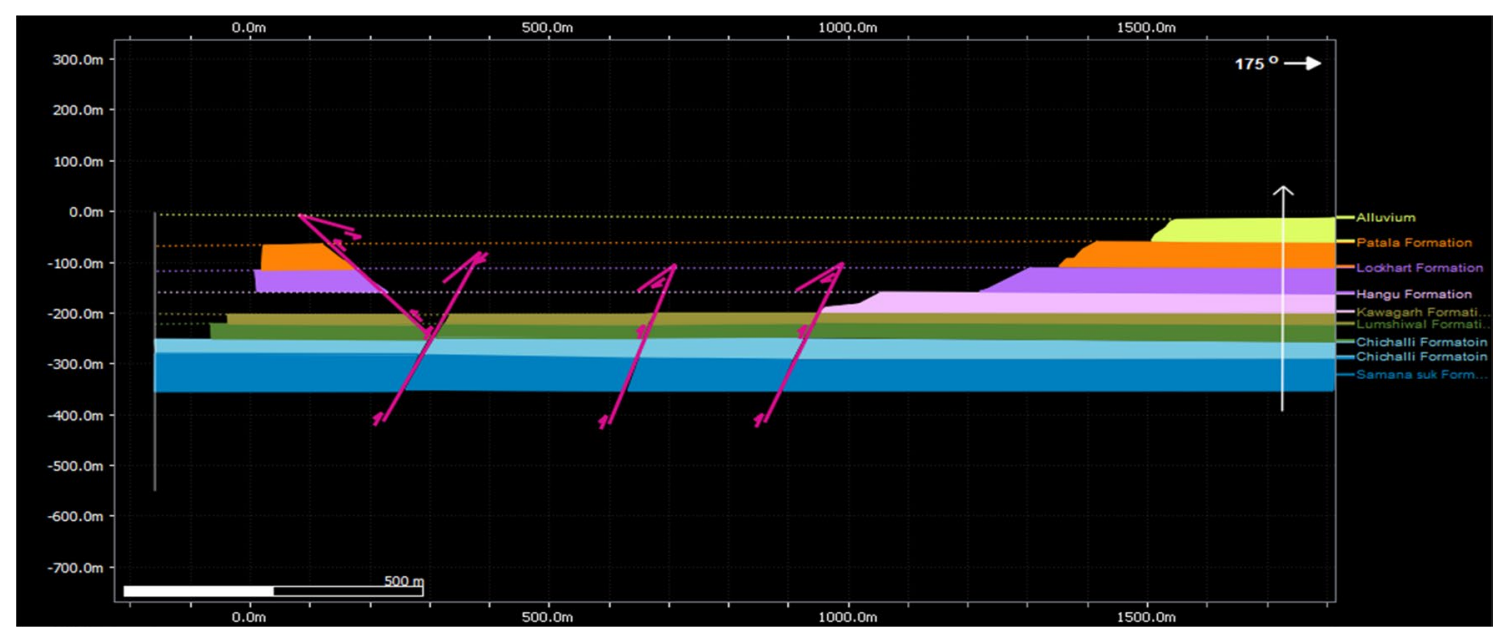

Fig. 10 displaying the retrodeformed strata from Paleocene to Jurassic rocks to its original position with flexural slip folding deformation mechanism

where $\Delta L=\mathrm{Lr}-\mathrm{Ld}, . \mathrm{Lr}=$ Restored length, $\mathrm{Ld}=$ Deformed length, $\Delta L=$ Total changed in length.

\begin{tabular}{llll}
\hline Deformed & Restored & $\begin{array}{l}\text { Total change in } \\
\text { length }\end{array}$ & $\begin{array}{l}\text { Percentage of } \\
\text { shortening }\end{array}$ \\
\hline Length, Ld (m) & Length, Lr (m) & $\begin{array}{l}\Delta L=\mathrm{Lr}-\mathrm{Ld} \\
(\mathrm{m})\end{array}$ & $\begin{array}{l}\%=\Delta L / \mathrm{Lr} \times 100 \\
(\%)\end{array}$ \\
1610 & 2000 & 390 & 19.5 \\
\hline
\end{tabular}

The above calculations employ that during the formation of Main Boundary Thrust fault, the Kahi area was exposed to the tectonic forces which prognosticated $19.5 \%$ shortening in rock sequences from Jurassic to Eocene rocks along Khware Khwar, Kahi Nizampur along the cross section A-B. This further implies that the subject mapped area has been intensely deformed by the tectonic stresses since the formation and existence of MBT which evidently disclose that these forces are the major key inducers for structural variations (Fig. 10).

\section{Discussion}

Tectonic forces originating from the formation of MBT caused different types of deformation in the form of folds, faults, synclines and anticlines, etc. This deformation also altered the stratigraphic sequences of the Kahi Gorge area, ranging from Eocene and Paleocene to Cretaceous and Jurassic particularly in the mapped area. The constructed geological map shows the major folds and faults exposed in the Kahi Gorge area are intensely deformed. Folds in the area mostly have east-west orientation, which indicates that north-south compressional stresses were at play. Deformational stresses caused the four Kahi thrusts, i.e., KT1, KT2, KT3 and KT4, to form. In all these main faults, older sequences have been thrusted over younger stratigraphic sequences. The deformations in the area produce large-scale synclines and anticlines in stratigraphic sequences from Eocene to Jurassic rocks due to which several formations repeated frequently while some formations have not been exposed as they formed the cores of anticlines. The restoration of the constructed cross sections $\mathrm{AB} \& \mathrm{CD}$ employs that during the formation of Main Boundary Thrust fault, the Kahi area was exposed to the tectonic forces which forecasted $19.5 \%$ shortening in rock sequences from Jurassic to Eocene rocks along Khware Khwar, Kahi Nizampur. This additional infers that the area has intensely deformed by the tectonic stresses since the formation and presence of MBT which obviously reveal that these forces are the major key inducers for structural variations.

The conclusion of our research work is as follows:

- The direction of deformational stresses is north-south which can be demonstrated from orientation of folds and En échelon Gash veins.

- The study area comprises of lithostratigraphy units ranging in age from Jurassic to Paleocene.

- Majority of the structures in the study area are oriented east-west.

- Majority of formation show verging toward the north, while some of the formations verge toward the south.

- The area is severely deformed marked by the southward verging thrust faults. (Kahi-1, Kahi-2, Kahi-3).

- The structural trend of the area shows the north-south oriented compressional stresses.

- The study area is dominated by extensional fractures. 
Acknowledgements Mr. Muhammad Yaseen thanks the Chairman, faculty, and staff of the Department of Geology, Abdul Wali Khan University Mardan for providing field facility to the study area. We are also grateful to Prof. Dr. Sajjad Ahmad Department of Geology, University of Peshawar for initial review the field data. The authors are grateful to the two anonymous reviewers for the appropriate and technical suggestions for improving the MS. The recommendations of including new references and revising the figures/diagrams by the reviewers further heightened the clarity of the paper. PETEX highly acknowledges to provide MOVE suite academic licenses to NCEG.

Funding The author(s) received no specific funding for this work.

\section{Declarations}

Conflict of interest The author declares that they do not have any conflict of interest.

Open Access This article is licensed under a Creative Commons Attribution 4.0 International License, which permits use, sharing, adaptation, distribution and reproduction in any medium or format, as long as you give appropriate credit to the original author(s) and the source, provide a link to the Creative Commons licence, and indicate if changes were made. The images or other third party material in this article are included in the article's Creative Commons licence, unless indicated otherwise in a credit line to the material. If material is not included in the article's Creative Commons licence and your intended use is not permitted by statutory regulation or exceeds the permitted use, you will need to obtain permission directly from the copyright holder. To view a copy of this licence, visit http://creativecommons.org/licenses/by/4.0/.

\section{References}

Awais M, Akhtar N, Ishaq M (2012) Geological mapping and structural analysis of a part of Kala-Chitta range, Kahi Village, Nizampur Khyber Pakhtunkhwa. Pak J Hydrocarb Res 22:13-23

Burbank DW, Johnson GD (1982) Intermontane-basin development in the past 4 myr in the north-west Himalaya. Nature 298(5873):432-436

Calkins JA, Offield TW, Abdullah SKM, Tayyab Ali S (1975) Geology of the southern Himalaya in Hazara, Pakistan, and adjacent areas. US Geol Surv Prof Pap 716:29
Ghauri AAK, Pervez MK, Riaz M, Rehman OU, Ahmad I, Ahmad S (1991) The structure and tectonic setting of Attock-cherat and kalachitta ranges in Nizampur area NWFP Pakistan. Kashmir J Geol 8(9):99-109

Hashmi SI, Jan IU, Khan S, Ali N (2018) Depositional, diagenetic and sequence stratigraphic controls on the reservoir potential of the Cretaceous Chichali and Lumshiwal formations, Nizampur Basin. Pak J Himal Earth Sci 51(2A):44-65

Hylland MD, Riaz M (1988) Stratigraphy and structure of the southern Gandghar range, Pakistan. Geol Bull Univ Peshawar 1:15-24

Omar AA, Lawa FA, Sulaiman SH (2015) Tectonostratigraphic and structural imprints from balanced sections across the northwestern Zagros fold-thrust belt, Kurdistan region. NE Iraq Arab J Geosci 8(10):8107-8129

Ullah Khan E, Saleem M, Naseem AA, Ahmad W, Yaseen M, Khan TU (2020) Microfacies analysis, diagenetic overprints, geochemistry, and reservoir quality of the Jurassic Samanasuk Formation at the Kahi Section, Nizampur Basin, NW Himalayas, Pakistan. Carbonates Evaporites 35(3):1-17

Wadood B, Awais M, Bilal M, Ishaq M, Ahmad L, Zafar Z (2019) Reservoir characterization and modelling with diagenetic trends of carbonates of the Kawagarh formation: a section exposed in the Kala-Chitta range, Pakistan. Int J Econ Environ Geol 10(2):105-111

Yaseen M, Wahid S, Ahmad S, Rehman G, Ahmad J, Anjum MN, Mehmood M (2021a) Tectonic evolution, prospectivity and structural studies of the hanging wall of Main Boundary Thrust along akhurwal-kohat transect, Khyber Pakhtunkhwa: implications for future exploration. Arab J Geosci 14(4):1-17

Yaseen M, Naseem AA, Ahmad J, Mehmood M, Anjum MN (2021b) Integrated Approach for Inventories and quantitative assessment of geological and paleontological sites from precambrian to quaternary successions in the Salt Range. Pak Geoheritage 13(2): $1-24$

Yeats RS, Hussain A (1987) Timing of structural events in the Himalayan foothills of northwestern Pakistan. Geol Soc Am Bull 99(2):161-176

Publisher's Note Springer Nature remains neutral with regard to jurisdictional claims in published maps and institutional affiliations 